\title{
Detection of SARS-CoV-2 RNA in Medical Wastewater in Wuhan During the COVID-19 Outbreak
}

\author{
Jun-Bo Zhou ${ }^{1} \cdot$ Wen-Hua Kong ${ }^{1} \cdot$ Sheng Wang ${ }^{1} \cdot$ Yi-Bing Long ${ }^{1} \cdot$ Lian-Hua Dong $^{2} \cdot$ Zhen-Yu He $^{1}$ (D) \\ Man-Qing Liu' ${ }^{1}$ (B)
}

Received: 28 July 2020 / Accepted: 14 January 2021 / Published online: 3 May 2021

(c) Wuhan Institute of Virology, CAS 2021

\section{Dear Editor,}

The outbreak of 2019 novel coronavirus disease (COVID-19), caused by the infection of SARS-CoV-2, was first reported in Wuhan, China (Kong et al. 2020a, 2020b) and has become the most serious public health emergency in the century (Matsuzaki et al. 2010; World Health Organization 2020). The fecal shedding of SARS-CoV-2 has been proven by the viral strains isolated from COVID-19 patient's stool specimens (Wang et al. 2020). It proposed the possibility that contaminated waste water and fomites might be involved in disease transmission (Tang et al. 2020), especially at the healthcare facilities with large number of patients. Several studies have demonstrated the possible transmission of SARS-CoV-2 by wastewater (Kitajima et al. 2020; La Rosa et al. 2020; Orive et al. 2020). Here we report the results of a small scale experimental investigation, showing that low level of SARS-CoV-2 RNA was present in the wastewater from COVID-19 related facilities in Wuhan, China during the outbreak.

As the first epicenter of the pandemic, Wuhan has experienced a catastrophic medical need that once collapsed the healthcare system of the city. In order to handle the situation and brake the transmission chain of SARS-CoV-2, a threelayer COVID-19 healthcare facility system was built, including 48 designated hospitals for COVID-19 patients in

Jun-Bo Zhou and Wen-Hua Kong contributed equally to this work.

Supplementary Information The online version contains supplementary material available at https://doi.org/10.1007/s12250021-00373-z.

Man-Qing Liu

liumq33@hotmail.com

$\triangle$ Zhen-Yu He

hosan9174@163.com

1 Wuhan Center for Disease Control and Prevention, Wuhan 430024, China

2 National Institute of Metrology, Beijing 100013, China severe or critical conditions, 14 Fangcang shelter hospitals treating patients with mild symptoms and over 100 community quarantine spots for the isolation and health monitoring of recovered patients, suspected patients and close contacts (Chen et al. 2020) (Supplementary Table S1).

The study involved four types of facilities, including two designated hospitals, two Fangcang shelter hospitals, two community quarantine spots and two urban wastewater treatment plants (WWTPs) (Table 1). All the six hospitals/quarantine spots were equipped with permanent or temporary onsite liquid waste treatment system (LWTS). On March 4th, 2020, water samples were collected from 10 sampling sites, including the water outlet of onsite LWTS at each healthcare facility, as well as the water inlet and outlet of WWTPs. Two liters of specimen were collected with sterile containers at each site. Specimens were tested for total residual chlorine immediately using 3, 3', 5, 5'-tetramethylbenzidine colorimetry. The nucleic acid was extracted from $200 \mu \mathrm{L}$ of specimen using a GeneRotex automated nucleic acid extraction system (Tianlong, Xi'an, China) and a commercial qPCR assay (Daan Gene, Guangzhou, China) was employed to detect the presence of SARS-CoV-2 RNA. The assay's limit of detection (LoD) for SARS-CoV-2 ORFlab and $N$ gene was 500 copies $/ \mathrm{mL}$ with cut-off cycle of threshold $(\mathrm{Ct})$ value of 40 . As shown in Table 1, samples from healthcare facilities had higher concentrations of residual chlorine $(1 \mathrm{mg} / \mathrm{L}$ to $>10 \mathrm{mg} / \mathrm{L})$ than those from WWTPs $(<0.5 \mathrm{mg} / \mathrm{L})$, which was related to the chlorine-containing disinfectant uses at the onsite liquid waste treatment sites. Although most samples were negative in the SARS-CoV-2 RNA qPCR test, sample \#6 from a quarantine spot presented a weak positive result for the $N$ gene $(\mathrm{Ct}$ value $=38.96$ ). The detection rates of viral RNA in 8 facilities were zero for ORFlab fragment and $12.5 \%$ for $N$ gene.

In order to identify the potential low-level viral RNA contamination, one water sample from each type of facility was chosen to be concentrated and further tested for SARSCoV-2 RNA (Table 1). For each sample, a total of $500 \mathrm{~mL}$ homogeneous specimen was collected on $47 \mathrm{~mm}$ diameter 
Table1 Presence of SARS-CoV-2 RNA in the wastewater from different locations in Wuhan, China, during the COVID-19 outbreak

\begin{tabular}{|c|c|c|c|c|c|c|c|c|c|c|}
\hline \multirow{3}{*}{\multicolumn{2}{|c|}{ Facility (Patients capacity) }} & \multirow[t]{3}{*}{ Sampling site } & \multirow{3}{*}{$\begin{array}{l}\text { Concentration } \\
\text { of chlorine } \\
\text { residual } \\
(\mathrm{mg} / \mathrm{L})\end{array}$} & \multirow{2}{*}{\multicolumn{2}{|c|}{$\begin{array}{l}\begin{array}{l}\text { Before } \\
\text { concentration }\end{array} \\
\text { qPCR result }(\mathrm{Ct} \\
\text { value })\end{array}$}} & \multicolumn{5}{|c|}{ After concentration $(250: 1)$} \\
\hline & & & & & & \multicolumn{2}{|c|}{$\begin{array}{l}\text { qPCR result }(\mathrm{Ct} \\
\text { value) }\end{array}$} & \multicolumn{3}{|c|}{$\begin{array}{l}\text { ddPCR result } \\
\text { (copies/reaction) }\end{array}$} \\
\hline & & & & ORF1ab & $\mathrm{N}$ & ORF1ab & $\mathrm{N}$ & ORF1ab & $\mathrm{N}$ & $\mathrm{E}$ \\
\hline \multicolumn{11}{|c|}{ Designated hospital } \\
\hline 1 & Wuchang Hospital (504) & $\begin{array}{l}\text { Outlet of the West Zone } \\
\text { onsite LWTS }\end{array}$ & $>10$ & Negative & Negative & NT & NT & NT & NT & NT \\
\hline 2 & $\begin{array}{l}\text { The Central Hospital of } \\
\text { Wuhan (543) }\end{array}$ & $\begin{array}{l}\text { Outlet of the onsite } \\
\text { LWTS }\end{array}$ & 6 & Negative & Negative & 35.90 & 33.63 & 134 & 42 & 10.2 \\
\hline \multicolumn{11}{|c|}{ Fangcang shelter hospital } \\
\hline 3 & $\begin{array}{l}\text { Jiangxia Cabin Hospital } \\
(564)\end{array}$ & $\begin{array}{l}\text { Outlet of the onsite } \\
\text { LWTS }\end{array}$ & 1 & Negative & Negative & NT & NT & NT & NT & NT \\
\hline 4 & $\begin{array}{l}\text { Jiangan Cabin Hospital } \\
\text { (1000) }\end{array}$ & $\begin{array}{l}\text { Outlet of the onsite } \\
\text { LWTS }\end{array}$ & 3 & Negative & Negative & 33.64 & 32.31 & 402 & 26 & 36 \\
\hline \multicolumn{11}{|c|}{ Community quarantine spot } \\
\hline 5 & $\begin{array}{l}\text { Guanggu New Beacon } \\
\text { Hotel }(60)\end{array}$ & $\begin{array}{l}\text { Outlet of the onsite } \\
\text { LWTS }\end{array}$ & 5 & Negative & Negative & NT & NT & NT & NT & NT \\
\hline 6 & $\begin{array}{l}\text { Jinyinhu New Beacon } \\
\text { Hotel (167) }\end{array}$ & $\begin{array}{l}\text { Outlet of the onsite } \\
\text { LWTS }\end{array}$ & $\begin{array}{l}\text { NT (high } \\
\text { turbidity) }\end{array}$ & Negative & 38.96 & Negative & Negative & 44 & 6.6 & 11 \\
\hline \multicolumn{11}{|c|}{$W W T P$} \\
\hline 7 & Qingshan WWTP & South 3\# wastewater inlet & $<0.5$ & Negative & Negative & NT & NT & NT & NT & NT \\
\hline 8 & Qingshan WWTP & South $3 \#$ water outlet & $<0.5$ & Negative & Negative & NT & NT & NT & NT & NT \\
\hline 9 & Hanxi WWTP & Main wastewater inlet & $<0.5$ & Negative & Negative & Negative & 36.15 & 110 & 0 & 0 \\
\hline 10 & Hanxi WWTP & Main water outlet & $<0.5$ & Negative & Negative & NT & NT & NT & NT & NT \\
\hline
\end{tabular}

$W W T P$ wastewater treatment plant, $q P C R$ quantitative PCR, $d d P C R$ droplet digital PCR, LWTS liquid waste treatment system, $C t$ cycle of threshold, $N T$ not tested.

EZ-PAK filter with $0.45 \mu \mathrm{m}$ pore (Millipore, US) and the retentate was eluted in $2 \mathrm{~mL}$ of phosphate buffer saline $(\mathrm{pH}$ 9.5) (Zhou et al. 2010). The concentrated samples then underwent nucleic acid extraction and qPCR test as above. In addition, droplet digital PCR (ddPCR) assay stargeting ORFlab, $N$ gene and $E$ gene were exploited. Target 1 (ORFlab gene) comprised forward primer CCCTGTGGGT TTTACACTTAA, reverse primer ACGATTGTGCATCA GCTGA, and the probe 5'-FAM-CCGTCTGCGGTATGTGGAAAGGTTATGG-BHQ1-3'. Target 2 ( $N$ gene) comprised forward primer GGGGAACTTCTCCTGCTAGAAT, reverse primer CAGACATTTTGCTCTCAAGCTG, and the probe 5'-FAM- TTGCTGCTGCTTGACAGATT-TAMRA-3'. Target 3 ( $E$ gene) comprised forward primer ACAGGTACGTTAATAGTTAATAGCGT, reverse primer ATATTGCAG CAGTACGCACACA, and the probe 5'- FAM-ACACTAG CCATCCTTACTGCGCTTCG-BBQ- ${ }^{\prime}$. The ddPCR tests were performed on a QX200 droplet digital PCR system (BioRad, USA) as previously described (Chan et al. 2020; Corman et al. 2020; Dong et al. 2020). The LoDs of ddPCR were 2 copies/reaction for all three targets. SARS-CoV-2 RNA was detected in all four concentrated samples by either qPCR or ddPCR. The detection rates of qPCR rose to $50 \%$ for ORF1ab and $75 \%$ for $N$ gene, and those of ddPCR were $100 \%$ for ORFlab, $75 \%$ for $N$ gene and $75 \%$ for $E$ gene. Both were much higher than the detection rates before concentration. Samples from the designated hospital and Fangcang shelter hospital presented higher viral RNA levels than those from quarantine spot and WWTP. Notably, the qPCR result of concentrated sample \#6 was negative for $N$ gene, which could be related to the high level of the interfering substance in the concentrated wastewater. The ddPCR assay, on the other hand, detected SARS-CoV-2 RNA in the same sample, showing high sensitivity for the complex sample including multifarious wastewater (Singh et al. 2017). Besides, as samples were concentrated with $0.45 \mu \mathrm{m}$ filter, instead of filter with $0.22 \mu \mathrm{m}$ pore that easily clogged by the wastewater sample in the prior test, the concentration efficiency might be compromised (Ahmed et al. 2020; Hennechart-Collette et al. 2020).

This study was conducted in the early of March 2020, the later stage of COVID-19 outbreak in Wuhan. Although our observation had a very limited sample number, the SARSCoV-2 RNA presence in wastewater appeared to be a pervasive phenomenon in Wuhan, when there were still over 20 thousand COVID-19 patients in the city. Viral RNA was not only found in the liquid waste of medical facilities, but also in 
the urban sewerage network, which was in accordance with the recent report that viral RNA was detected in the wastewater surveillance in the Netherlands, the United States and Sweden (La Rosa et al. 2020; Mallapaty 2020; Orive et al. 2020). However, the trace of SARS-CoV-2 RNA did not indicate the presence of infectious viral particles. The viral RNA level detected in our study was very low (under or close to the LoD of qPCR assay), indicating wastewater unlikely to be a spread source in this scenario. Adequate disinfection of wastewater is essential to control the source of infection. In order to eliminate the wastewater contamination caused by centralized COVID19 healthcare facilities, additional disinfection of drainage system such as continuous disinfectant drip (Supplementary Figure S1) was conducted in Wuhan, as well as the standard onsite wastewater disinfection.

The detection of SARS-CoV-2 RNA from wastewater not only provides a warning sign for the virus's arrival in community, but also implies the possible transmission of SARS-CoV-2, especially in the outbreak city with centralized isolation hospitals. Considering COVID-19 pandemic has caused lack of testing resources in many countries and regions, we call for particular attention to the surveillance and efficient disinfection of wastewater from COVID-19 related facilities, as well as the systematic study on the role of polluted wastewater in SARS-CoV-2 transmission.

Acknowledgement This work was supported by The Emergency Scientific Research Projects for COVID-19 from Wuhan Science and Technology Bureau (No. 2020020101010008) and Wuhan Municipal Health Commission (No. EX20D18).

\section{Compliance with Ethics Guidelines}

Conflict of interest The authors declare that they have no conflict of interest.

Animal and Human Rights Statement This article does not contain any studies with human or animal subjects performed by any of the authors.

\section{References}

Ahmed W, Bertsch PM, Bivins A, Bibby K, Farkas K, Gathercole A, Haramoto E, Gyawali P, Korajkic A, McMinn BR, Mueller JF, Simpson SL, Smith WJM, Symonds EM, Thomas KV, Verhagen R, Kitajima M (2020) Comparison of virus concentration methods for the RT-qPCR-based recovery of murine hepatitis virus, a surrogate for SARS-CoV-2 from untreated wastewater. Sci Total Environ 739:139960

Chan JF, Yip CC, To KK, Tang TH, Wong SC, Leung KH, Fung AY, $\mathrm{Ng} \mathrm{AC}$, Zou Z, Tsoi HW, Choi GK, Tam AR, Cheng VC, Chan KH, Tsang OT, Yuen KY (2020) Improved molecular diagnosis of COVID-19 by the novel, highly sensitive and specific
COVID-19-RdRp/Hel real-time reverse transcription-PCR assay validated in vitro and with clinical specimens. J Clin Microbiol 58:e00310-e00320

Chen S, Zhang Z, Yang J, Wang J, Zhai X, Barnighausen T, Wang C (2020) Fangcang shelter hospitals: a novel concept for responding to public health emergencies. Lancet 395:1305-1314

Corman VM, Landt O, Kaiser M, Molenkamp R, Meijer A, Chu DK, Bleicker T, Brunink S, Schneider J, Schmidt ML, Mulders DG, Haagmans BL, van der Veer B, van den Brink S, Wijsman L, Goderski G, Romette JL, Ellis J, Zambon M, Peiris M, Goossens H, Reusken C, Koopmans MP, Drosten C (2020) Detection of 2019 novel coronavirus (2019-nCoV) by real-time RT-PCR. Euro Surveill 25:2000045

Dong L, Zhou J, Niu C, Wang Q, Pan Y, Sheng S, Wang X, Zhang Y, Yang J, Liu M, Zhao Y, Zhang X, Zhu T, Peng T, Xie J, Gao Y, Wang D, Zhao Y, Dai X, Fang X (2020) Highly accurate and sensitive diagnostic detection of SARS-CoV-2 by digital PCR. Talanta 224:121726

Hennechart-Collette C, Dehan O, Fraisse A, Martin-Latil S, Perelle S (2020) Evaluation of three different filters and two methods for recovering viruses from drinking water. J Virol Methods 284:113939

Kitajima M, Ahmed W, Bibby K, Carducci A, Gerba CP, Hamilton KA, Haramoto E, Rose JB (2020) SARS-CoV-2 in wastewater: State of the knowledge and research needs. SciTotal Environ 739:139076

Kong WH, Li Y, Peng MW, Kong DG, Yang XB, Wang L, Liu MQ (2020a) SARS-CoV-2 detection in patients with influenza-like illness. Nat Microbiol 5:675-678

Kong WH, Zhao R, Zhou JB, Wang F, Kong DG, Sun JB, Ruan QF, Liu MQ (2020b) Serologic response to SARS-CoV-2 in COVID19 patients with different severity. Virol Sin 35:752-757

La Rosa G, Iaconelli M, Mancini P, Ferraro GB, Veneri C, Bonadonna L, Lucentini L, Suffredini E (2020) First detection of SARS-CoV-2 in untreated wastewaters in Italy. Sci Total Environ 736:139652

Mallapaty S (2020) How sewage could reveal true scale of coronavirus outbreak. Nature 580:176-177

Matsuzaki Y, Mizuta K, Takashita E, Okamoto M, Itagaki T, Katsushima F, Katsushima Y, Nagai Y, Nishimura H (2010) Comparison of virus isolation using the Vero E6 cell line with real-time RT-PCR assay for the detection of human metapneumovirus. BMC Infect Dis 10:170

Orive G, Lertxundi U, Barcelo D (2020) Early SARS-CoV-2 outbreak detection by sewage-based epidemiology. Sci Total Environ 732:139298

Singh G, Sithebe A, Enitan AM, Kumari S, Bux F, Stenstrom TA (2017) Comparison of droplet digital PCR and quantitative PCR for the detection of Salmonella and its application for river sediments. J Water Health 15:505-508

Tang A, Tong ZD, Wang HL, Dai YX, Li KF, Liu JN, Wu WJ, Yuan C, Yu ML, Li P, Yan JB (2020) Detection of novel coronavirus by RT-PCR in stool specimen from asymptomatic child, China. Emerg Infect Dis 26:1337-1339

Wang W, Xu Y, Gao R, Lu R, Han K, Wu G, Tan W (2020) Detection of SARS-CoV-2 in different types of clinical specimens. JAMA 323:1843-1844

World health organization (2020) STEPS sample size calculator and sampling spreadsheet. https://www.who.int/ncds/surveillance/ steps/resources/sampling/en/. Accessed 28 July 2020

Zhou XH, Li H, Yang XF, Ke CW, Chen CD, Zheng HY, Zhou HQ, Chen QX, Zou LR (2010) Concentration and absolute quantitative detection of the norovirus of the water specimens. J Tropical Med 0:137-140 